\title{
An intrasellar cystic mass and hypopituitarism
}

\author{
S Iida, H Fujii, Y Tanaka, S Hayashi, T Nagareda, K Moriwaki
}

A 44-year-old man had suffered from headache, general fatigue and impotence for three months. Physical examination revealed a bitemporal visual field defect. Skull X-ray films showed ballooning of the sella turcica. Magnetic resonance imaging (MRI) revealed an intrasellar cystic mass compressing optic chiasma (figure). The cyst was removed by a transsphenoidal approach. Anterior pituitary function was evaluated by combined provocative testing (luteinising hormonereleasing hormone test, thyrotropin-releasing hormone test, and insulin tolerance test) before and 21 days after surgery (table).

Table Combined provocative testing before (B) and after (A) surgery

\begin{tabular}{|c|c|c|c|c|c|c|}
\hline \multicolumn{2}{|l|}{ Times (min): } & \multirow{2}{*}{$\begin{array}{l}0 \\
5.1\end{array}$} & \multirow{2}{*}{$\begin{array}{l}15 \\
3.9\end{array}$} & \multirow{2}{*}{$\frac{30}{2.3}$} & \multirow{2}{*}{$\frac{60}{4.0}$} & \multirow{2}{*}{$\frac{120}{5.2}$} \\
\hline Plasma glucose & B & & & & & \\
\hline$(3.9-6.1 \mathrm{mmol} / \mathrm{l})$ & A & 4.9 & 3.6 & 1.9 & 3.7 & 4.7 \\
\hline Plasma adrenocorticotropin & B & 2.6 & 3.3 & 3.3 & 4.2 & 4.0 \\
\hline$(2.0-11.5 \mathrm{pmol} / \mathrm{l})$ & A & 3.1 & 3.3 & 3.7 & 22.0 & 5.1 \\
\hline Serum cortisol & B & 38.6 & 52.4 & 57.9 & 113.1 & 104.8 \\
\hline$(110-505 \mathrm{pmol} / \mathrm{l})$ & A & 146.2 & 162.8 & 162.8 & 306.2 & 292.5 \\
\hline Serum growth hormone & B & 0.7 & 0.8 & 0.8 & 0.9 & 0.9 \\
\hline$(<1.46 \mu \mathrm{g} / 1)$ & $\mathbf{A}$ & 0.4 & 0.4 & 0.4 & 0.3 & 0.3 \\
\hline Serum prolactin & B & 4.9 & 9.2 & 9.9 & 7.0 & 5.3 \\
\hline$(<30 \mu \mathrm{g} / 1)$ & $\mathbf{A}$ & 4.4 & 10 & 9.5 & 7.4 & 5.7 \\
\hline Serum thyroid-stimulating hormone & B & 1.4 & 5.2 & 6.4 & 5.9 & 3.4 \\
\hline$(0.34-3.5 \mathrm{mU} / \mathrm{l})$ & A & 3.0 & 10.9 & 15.2 & 11.0 & 5.6 \\
\hline Serum luteinising hormone & B & 0.5 & 0.5 & 0.8 & 1.1 & 1.1 \\
\hline$(0.2-20 \mathrm{IU} / \mathrm{l})$ & A & 0.5 & 0.8 & 1.2 & 1.4 & 1.4 \\
\hline Serum follicle-stimulating hormone & $\mathbf{B}$ & 2.0 & 2.2 & 2.5 & 3.1 & 3.6 \\
\hline$(0.8-22.9 \mathrm{IU} / 1)$ & A & 2.5 & 2.8 & 3.1 & 3.4 & 3.5 \\
\hline
\end{tabular}

The numbers in parentheses indicate the normal range of basal hormone levels

\section{Minami-Wakayama National Hospital, Takinai, Shinjocho, Tanabe, Wakayama 646, Japan \\ Department of Internal Medicine S Iida \\ H Fujii \\ K Moriwaki \\ Department of \\ Neurosurgery \\ Y Tanaka \\ S Hayashi \\ Department of \\ Pathology \\ T Nagareda}

Accepted 16 October 1995

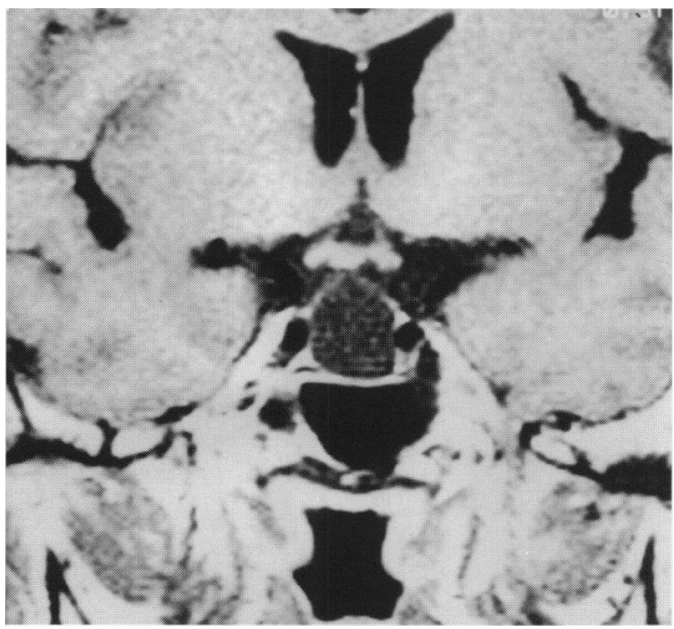

\section{Questions}

1 Suggest two causes of the man's illness.

2 How would you describe his endocrine status?
Figure T1-weighted MRI of an intrasellar arachnoid cyst. The coronal views demonstrate a cystic lesion arising within the sella with suprasellar extension. The difference in imaging characteristics between cerebrospinal fluid (CSF) within the cyst and the ventricle is related to the fact that the CSF within the arachnoid cyst is stagnant 


\section{Answers}

QUESTION 1

The most important causes of intrasellar cystic masses are shown in the box. Intrasellar arachnoid cysts are rare lesions that are hard to differentiate from intrasellar pituitary cysts or Rathke's cleft cysts. As adenomas and craniopharyngiomas are more common than cysts, the cyst is often misdiagnosed. An empty sella also should be ruled out. The empty sella freely communicates with the subarachnoid space above the diaphragma sellae on positive contrast computed tomography (CT) cisternography. In this patient, we excluded the empty sella because a cystic mass extended to the suprasellar lesion and had different imaging characteristics compared with the ventricle. We excluded a pars intermedia cyst because it was reported to be very small $(2-3 \mathrm{~mm}$ in diameter).

It is impossible to reach the diagnosis before surgery. The final diagnosis must wait for histological examination of the specimens obtained at the operation.

\section{QUESTION 2}

The patient presented with clinical symptoms of hypopituitarism. ${ }^{1-3}$ Combined provocative testing in the patient indicated the presence of panhypopituitarism pre-operatively.

\section{Discussion}

An intrasellar cystic mass was demonstrated by MRI in this patient. The cyst was removed by a transsphenoidal approach. The cyst contained a small amount of clear, colourless, fluid, in

1 Spaziante R, Divitiis E, Stella L, Cappabianca P, Donzelli R. Benign intrasellar cysts. Surg Neurol 1981; 15: 274-82. Baskin DS, Wilson CB. Transsphenoidal treatment of nonneoplastic intrasellar cysts, a report of 38 cases. $\mathfrak{F}$ Neurosurg 1984; 60: 8-13.

\begin{tabular}{|l|}
\hline Causes of intrasellar cystic masses \\
\hline - pars intermedia cysts \\
- Rathke's cleft cysts \\
- arachnoid cysts \\
- pituitary cysts (parenchymal or adenomatous) \\
- miscellaneous cysts (epidermoid cysts, \\
cysticercosis cysts) \\
\hline
\end{tabular}

contrast to the yellowish mucoid fluid in Rathke's cleft cysts. Histological study revealed that the walls of the cysts were composed of connective tissue and arachnoid cells. Thus, an intrasellar arachnoid cyst was diagnosed. Postoperatively, the provocative test demonstrated that responses of adenocorticotropin, cortisol, and thyroid-stimulating hormone were normalised. Hypopituitarism due to an intrasellar arachnoid cyst is very rare; until now, one case has been reported by Spaziante et $a l^{1}$, four cases by Baskin $e t a l^{2}$ and two cases by Meyer $e t$ $a l .{ }^{3}$ Only one of these patients showed partial recovery in anterior pituitary function after surgery.

An intrasellar arachnoid cyst should be considered as one of the possible disorders causing hypopituitarism. Surgical removal of the cyst results in restoration of the anterior pituitary function when detected and treated in an early stage.

\section{Final diagnosis}

An intrasellar arachnoid cyst.

Keywords: intrasellar arachnoid cyst, hypopituitarism

3 Meyer FB, Carpenter SM, Laws ER Jr. Intrasellar arachnoid cysts. Surg Neurol 1987; 28: 105-10. 